\section{Dance Research}

Committee on Research in Dance (CORD)
Journal

Volume 10/1

Fall/Winter 1977-1978

$\$ 3.00$

\title{
CONTENTS
}

\section{ARTICLES}

". . .to make amends for One ill Dance": Conventions for Dancing in Restoration Plays

Curtis A. Price

Source Materials for the Study of French Dance (1643-1793)

Christena L. Schlundt

The Grand Jeté En Tournant Entrelacé (Tour Jeté): An Analysis Through Motion Photography

Men as Women: Female Dance Symbolism in Walbiri Men's Rituals
Marilyn Hinson, Susan Buckman, Judith Tate, Claudine Sherrill

Stephen A. Wild

\section{REVIEWS}

Symphonic Principles of Tchaikovsky's Ballets [Simfonicheskie printsipy baletov Chaikovskogo]. Yuliya Andreyevna Rozanova

Roland John Wiley

Indian Dances of North America: Their Importance to Indian Life. Reginald Laubin and Gladys Laubin

Jonathan E. Reyman

Arts and Aesthetics: An Agenda for the Future. Stanley S. Madeja, ed.

Kent Anderson

Human Characteristics and School Learning. Benjamin S. Bloom

Richard Cabezas

Knowing in My Bones. Ruth Foster

Dorothy Vislocky

Dance Beat: Selected Views and Reviews, 1967-1976. Deborah Jowitt

Suzanne Walther

Dictionary Catalog of the Dance Collection.

Christena L. Schlundt

\section{REPORTS}

The Performing Arts Program of the Asia Society

Gloria B. Strauss

1977 ICKL Conference in England

The Israel Ethnic Dance Project

Lucy Venable, Mary Jane Warner

Judith Brin Ingber

Major New Coalition of Arts Education Associations Formed

Elizabeth Burtner 


\section{Dance Research Journal}

\section{Committee on Research in Dance (CORD)}

The Dance Research Journal, a biannual publication of CORD, includes articles, reviews, reports, research materials, commentaries and announcements on dance and related fields. Single copies $\$ 3.00$ (free to CORD members). For further information, see publications under CORD INFORMATION section.

\section{Editor:}

Elizabeth Burtner, 1400 Stuart Road, Herndon, VA 22070

Co-Editors: (beginning with 10/2)

Dianne L. Woodruff, York University, FFA/Dance, 4700 Keele Street, Downsview, Ontario, M3J 1P3 Canada

Nancy Reynolds, 25 West 68th Street, New York, N.Y. 10023

\section{Research Materials Editor:}

Betty True Jones, 47 North Tulane Street, Princeton, N.J. 08540

\section{Associate Editors:}

Richard Cabezas, Education-1100 Palisade Avenue, No. 4C, Union City, N.J. 07087

Judith Lynne Hanna, Social Sciences/Ethnic Studies-School of Arts and Humanities, The University of Texas at Dallas, Richardson, TX 75080

Lucy Venable, Dance Notation-424 D Street, Lincoln, NE 68502

Roland John Wiley, Music-School of Music, The University of Michigan, Stearns Building, Ann Arbor, MI 48105

(added to the staff beginning with 10/2)

Beth Genné, Films-2120 North Cleveland, Chicago, IL 60614

Nancy Goldner, Contemporary Performance and Criticism-5 West 86th Street New York, N.Y. 10024

Anne Hatfield, Philosophy-430 West Diversey Parkway, Apt. 305, Chicago, IL 60614

Debra Hickenlooper Sowell, Libraries and Archives-474 Broadway, Apt. 8, Cambridge, MA 02138

Irene Dowd, Biomechanics and Kinesiology-53 Gansevort, New York, N.Y. 10014

Christena L. Schlundt, Dance History-Program in Dance, University of California at Riverside, Riverside, CA 92521

Jill Silverman, Dance History-16 Charles Street, No. 39, New York, N.Y. 10014

Sally R. Sommer, Theatre-9 West 10th Street, New York, N.Y. 10011

Research Materials Contributors: (includes the above listed Associate Editors)

Irene Aschwanden, France and Switzerland-Tiller Street 46, 3005 Berne, Switzerland

Margaret Thompson Drewal, Africa, Caribbean, Afro-American Studies-3360 Kildare Road, Cleveland, OH 44118

Anthony V. Shay, Balkans and Middle East-3817 Effie Street, Los Angeles, CA 90026

Gloria B. Strauss, China-221 North Little Tor Road, New City, New York 10956

(added to the staff beginning with 10/2)

Susan Gould, Italy-Lugarno Soderini 27, 50124 Firenze, Italy

Stephanie Jordan, England-46 Clifton Gardens, London W9, U.K.

Zbigniew Korycki, Poland-PWSM, 00-368 Warsaw, ul. Okolnik 2, Poland

Production Staff:

Lynn Price Ager, Lois Andreasen, Brook Andrews, Joyce R. Malm, JoAnne C. Sellars, Suzanne Walther, Linda del Zio Zoffer

Copyright $\subset 1978$

by the Committee on Research in Dance

All Rights Reserved

Library of Congress Catalog Card No. 76-12179 